\title{
Effect of Gamma Irradiation on Fluoride Release and Antibacterial Activity of Resin Dental Materials
}

\author{
Fabíola Galbiatti de CARVALHO ${ }^{1}$ \\ Suzana Beatriz Portugal de FUCIO ${ }^{1}$ \\ Fernanda Miori PASCON ${ }^{2}$ \\ Kamila Rosamilia KANTOVITZ ${ }^{2}$ \\ Lourenço CORRER-SOBRINHO ${ }^{1}$ \\ Regina Maria PUPPIN-RONTANI ${ }^{2}$
}

\begin{abstract}
${ }^{1}$ Department of Dental Materials, Piracicaba Dental School, State University of Campinas, Piracicaba, SP, Brazil
${ }^{2}$ Department of Pediatric Dentistry, Piracicaba Dental School, State University of Campinas, Piracicaba, SP, Brazil
\end{abstract}

\begin{abstract}
This study evaluated the effect of gamma irradiation on fluoride release and antibacterial activity of FluroShield (FS) and Clearfil Protect Bond (CPB). Four groups were formed: G1-FS + gamma; G2-FS without gamma; G3-CPB + gamma; G4-CPB without gamma. For fluoride release analysis, 12 disks of each material were prepared and covered with nail polish, except for one side $\left(50.4 \mathrm{~mm}^{2}\right.$ area). G1 and G3 were sterilized with a $14.5 \mathrm{KGy}$ dose at $27^{\circ} \mathrm{C}$ for $24 \mathrm{~h}$, while G2 and G4 (controls) were not sterilized and were maintained under the same time and temperature conditions. Fluoride release measurements were made in duplicate $(n=6)$ by an ion specific electrode. The antibacterial activity of the CPB and FS against Streptococcus mutans after gamma sterilization was evaluated by the agar-disc diffusion method. The diameter of the zones of microbial growth inhibition was recorded after $48 \mathrm{~h}$. Data were analyzed statistically by ANOVA and Tukey's test $(\alpha=5 \%)$. Gamma sterilization decreased the fluoride release of FS by approximately $50 \%$, while CPB was not affected. There was no statistically significant difference $(\mathrm{p}>0.05)$ in the antibacterial effect of CPB between gamma and non-gamma sterilization groups. FS presented no antibacterial activity. Gamma irradiation decreased the fluoride release of FS, but did not affect the antibacterial activity of the studied materials.
\end{abstract}

Key Words: dentin bonding agents, pit-and-fissure sealants, fluoride, gamma rays.

\section{INTRODUCTION}

Artificial caries development has been used to simulate secondary caries formation in vitro and to evaluate the caries inhibition promoted by restorative materials with fluoride and antibacterial properties (1-3). Chemical (pH cycling and acid gels) $(1,4,5)$ and biological (microbial culture) (5) models are the most commonly used for producing artificial caries in vitro.

Many of the cariostatic effects of fluoridecontaining materials have been previously evaluated by artificial caries-formation systems in an acidic medium, without the involvement of microorganisms $(1,2)$. However, microorganisms may yield some information about the cariostatic effects of restorative materials on bacteria $(6,7)$. Furthermore, the antibacterial effect of adhesive systems containing the antibacterial monomer 12-methacryloyloxy-dodecylpyridinium bromide (MDPB) on caries inhibition must be investigated with the use of biological models. In this model, sterilization of the specimens restored before their immersion in the culture broth is very important to avoid contamination and to guarantee the specific action of the inoculated cariogenic microorganism. Consequently, appropriate sterilization is required, but it should not affect the biomechanical properties of dental tissues and materials.

The main sterilization methods used in investigations of caries inhibition by dental materials are ethylene oxide (EtO) (8) and gamma irradiation (2). The EtO gas sterilization process consists of 3 steps: being a cycle with specific gas concentration, a low-pressure autoclave, and temperature of $40-55^{\circ} \mathrm{C}(8)$. However,

Correspondence: Profa. Dra. Regina Maria Puppin-Rontani, Departamento de Odontopediatria, Faculdade de Odontologia de Piracicaba, Universidade de Campinas, UNICAMP, Avenida Limeira, 901, 13414-903 Piracicaba, SP, Brasil. Tel: +55-19-2106-5286. Fax: +55-19-2106-5218. e-mail: rmpuppin@fop.unicamp.br 
the pressure and temperature may alter the properties of dental materials in this type of study. Gamma irradiation from a cobalt- 60 source seems to be the method of choice because it sterilizes without high temperature and pressure, chemical products or gases. It is the typical method used for sterilizing hospital supplies and food, generating ionizing photons that cause irreparable cleavage or DNA fragmentation in microorganisms (9). Nevertheless, it remains unclear whether the gamma irradiation sterilization process could affect the fluoride release and antibacterial property of dental materials, as well as the tooth/restoration adhesion.

To the best of our knowledge, there is no study evaluating the effect of sterilization on the fluoride release and antibacterial property of resin dental materials. This study evaluated the effect of gamma irradiation on the fluoride release of resin-based dental materials and verify its effect on the antibacterial property of an MDPB-containing adhesive system (Clearfil Protect Bond - CPB) and a pit-and-fissure sealant (FluroShield - FS).

\section{MATERIAL AND METHODS}

The tested materials are described in Table 1.

Twelve cylindrical specimens of each material (FS and CPB) were fabricated using Teflon molds (4 mm diameter x $1.3 \mathrm{~mm}$ thick). FS and CPB were lightcured for 20 and $10 \mathrm{~s}$, respectively, according to the manufacturer's instructions. All specimens were coated with acid-resistant nail polish (Colorama; CEIL Com. Exp. Ind. Ltda., São Paulo, Brazil), except for one side $\left(50.4 \mathrm{~mm}^{2}\right.$ area) that was left for fluoride release measurement, and were stored in water at $37^{\circ} \mathrm{C}$ for $24 \mathrm{~h}$.

Four groups $(n=6)$ were formed for analysis of fluoride release: 1 - FS and gamma irradiation; 2 - FS without gamma irradiation; 3 - CPB adhesive and gamma irradiation and 4 - CPB adhesive without gamma irradiation. Specimens of group 1 and 3 were stored individually in bottles with $2 \mathrm{~mL}$ of deionized water and were sterilized in a gamma irradiation chamber (Gammacell 220 Excel, GC-220E; MDS Nordion, Ottawa, Canada) for $24 \mathrm{~h}$ at $27^{\circ} \mathrm{C}$ with a $14.5 \mathrm{KGy}$ dose (10). The irradiation time was determined taking into consideration the correction for radioactive decay of the gamma-ray source. Specimens of group 2 and 4 (controls groups) were stored individually in bottles with $2 \mathrm{~mL}$ of deionized water and kept at $27^{\circ} \mathrm{C}$ for the same time as groups 1 and 3. After $24 \mathrm{~h}$, fluoride measurements in the individual solutions were taken in duplicate.

In order to evaluate the release of fluoride, standard solutions were prepared from sodium fluoride solution with concentrations of $0.03,0.06,0.12,0.25$, 0.50 and $1.00 \mathrm{ppm} F$ to which was added TISAB III (Total Ionic Strength Adjustment Buffer; Termo Orion, Beverly, MA, USA) to obtain a constant background ionic strength. Standard solutions were used to plot the calibration graph. Fluoride release was detected using a fluoride-specific electrode (Orion 96-09) connected to a microprocessor ion analyzer (ORION EA- 940, Orion Research Inc., Boston, MA, USA). Readings were captured in milivolts $(\mathrm{mV})$ and transformed into $\mu \mathrm{gF}^{-} / \mathrm{mL}$ (ppm F-) by linear regression of the calibration curve. ANOVA and Tukey's tests were applied to verify the difference between the sterilization and non-sterilization groups for each material with regard to their fluoridereleasing capability. Significance level was set at 5\%.

The antibacterial effect of the CPB and FS against Streptococcus mutans after gamma steriliza-

Table 1. Tested materials.

\begin{tabular}{|c|c|c|c|}
\hline Material & Type & Composition & $\begin{array}{c}\text { Batch number and } \\
\text { manufacturer }\end{array}$ \\
\hline FluroShield & $\begin{array}{l}\text { Resin-based } \\
\text { pit-and-fissure }\end{array}$ & $\begin{array}{c}\text { Urethane modified Bis-GMA dimethacrylate, barium aluminoborosilicate } \\
\text { glass ( } 30 \%) \text {, polymerizable dimethacrylate resin, Bis-GMA, sodium } \\
\text { fluoride, dipentaerythritol pentaacrylate phosphate, titanium } \\
\text { dioxide, silica amorphous. }\end{array}$ & $\begin{array}{l}\text { \# } 317131 \\
\text { Dentsply/Caulk. } \\
\text { Milford, DE, USA }\end{array}$ \\
\hline $\begin{array}{l}\text { Clearfil } \\
\text { Protect } \\
\text { Bond }\end{array}$ & $\begin{array}{l}\text { Self-etching } \\
\text { adhesive } \\
\text { system }\end{array}$ & $\begin{array}{c}\text { Primer: MDP, MDPB, HEMA, hydrophobic methacrylate, water } \\
\text { Bond: MDP, Bis-GMA, HEMA, hydrophobic methacrylate, dI- } \\
\text { camphorquinone, N,N-diethanol-p-toluidine, silanated colloidal silica, } \\
\text { surface-treated sodium fluoride. }\end{array}$ & $\begin{array}{l}\text { \# 00027A/00017A } \\
\text { Kuraray, Okayama, } \\
\text { Japan }\end{array}$ \\
\hline
\end{tabular}


tion was evaluated by the agar-disc diffusion method. Twelve specimens of FS were made in the same way as described for the fluoride release test and were kept in water at $37^{\circ} \mathrm{C}$ for $24 \mathrm{~h}$. Six specimens were sterilized in the same gamma irradiation chamber (Gammacell 220 Excel, GC-220E; MDS Nordion) for $24 \mathrm{~h}$ at $27^{\circ} \mathrm{C}$ with a $14.5 \mathrm{KGy}$ dose (10), and the other 6 were stored in water at $27^{\circ} \mathrm{C}$ for $24 \mathrm{~h}$.

Two groups were formed: 1 - FS with gamma sterilization and 2 - FS without gamma sterilization. For CPB primer, $0.1 \mathrm{~mL}$ was inserted into 2 Eppendorf tubes. One Eppendorf tube was sterilized in a gamma irradiation chamber as described above and the other was kept at $27^{\circ} \mathrm{C}$ for $24 \mathrm{~h}$. Two groups were formed: 3 - CPB primer with gamma sterilization and 4 - CPB primer without gamma sterilization. A $S$. mutans strain (UA159) was grown in $5 \mathrm{~mL}$ brain heart infusion broth (BHI; Difco Laboratories, Detroit, MI, USA) for $24 \mathrm{~h}$ at $37^{\circ} \mathrm{C}$ to form a suspension. A sterile Petri dish $(20$ $\mathrm{x} 100 \mathrm{~mm}$ ) with a base layer containing $15 \mathrm{~mL}$ of BHI agar was prepared and $250 \mu \mathrm{L}$ of bacterial suspension was spread onto each BHI agar plate.

For $\mathrm{CPB}, 5 \mu \mathrm{L}$ primer of each group was applied on sterile filter paper discs (4 mm diameter x 1.5 mm thick) and $5 \mu \mathrm{L}$ of aqueous $0.12 \%$ chlorhexidine digluconate was also applied (positive control). A $5 \mu \mathrm{L}$ volume was chosen as the optimum for impregnation onto a paper disc without overflow of the test solution. For FS, the bottom surface of each polymerized specimen was placed on a BHI agar plate inoculated with $250 \mu \mathrm{L}$ of $S$. mutans (11). Six specimens were tested per group $(\mathrm{n}=6)$. The plates were kept for $2 \mathrm{~h}$ at room

Table 2. Fluoride release of the pit-and-fissure sealant and adhesive system after gamma sterilization.

\begin{tabular}{lccc}
\hline Materials & $\begin{array}{c}\text { Gamma } \\
\text { sterilization* } \\
(\mathrm{n}=6)\end{array}$ & $\begin{array}{c}\text { Non-gamma } \\
\text { sterilization } \\
(\mathrm{n}=6)\end{array}$ & $\mathrm{p}$ value \\
\hline Clearfil Protect & 0.218 & 0.287 & 0.07 \\
Bond & $(0.061)^{\mathrm{a}}$ & $(0.073)^{\mathrm{a}}$ & \\
& 0.314 & 0.611 & 0.03 \\
FluroShield & $(0.211)^{\mathrm{a}}$ & $(0.296)^{\mathrm{b}}$ & \\
\hline
\end{tabular}

* Values are expressed as mean (standard deviation) in ppm $\mathrm{F}^{-}$. Different letters in rows indicate statistically significant difference (ANOVA and Tukey's test; $\mathrm{p}<0.05$ ). temperature for the materials to diffuse. After that, they were incubated at $37^{\circ} \mathrm{C}$ for $24 \mathrm{~h}$ in a $5 \%$ supplemented $\mathrm{CO}_{2}$ environment. In a pilot study, primer and sealant were partially polymerized during gamma irradiation. Incompletely polymerized primer could be used for the antibacterial test because it remained fluid and could be applied to the paper discs. However, as FS is more viscous than the $\mathrm{CPB}$ primer the uncured material inside the Eppendorf tubes could not be removed, and so it was necessary to use polymerized specimens.

The diameter of the zones of microbial growth inhibition was recorded in millimeters with a digital caliper (Mitutoyo, São Paulo, SP, Brazil). Measurements were taken at the greatest distance between 2 points at the outer limit of the inhibition zone formed around the filter paper discs. This measurement was repeated 3 times and the mean was computed for each filter paper disk. Statistical analysis was done by ANOVA and Tukey's test to compare the inhibition zones of gamma sterilization and non-gamma sterilization groups against $S$. mutans strain at a $5 \%$ level of significance.

\section{RESULTS}

Fluoride release of FS decreased by almost $50 \%$ in the gamma sterilization group $(\mathrm{p}=0.03)$. Fluoride release of CPB was not affected by the gamma irradiation process $(\mathrm{p}=0.07)($ Table 2$)$. Furthermore, there was no statistical difference in antibacterial effect of CPB between the gamma sterilization and non-gamma sterilization groups $(\mathrm{p}=0.616)$ (Table 3). FS presented no antibacterial activity against $S$. mutans in both groups.

Table 3. Zones of microbial growth inhibition of Clearfil Protect Bond (primer) and FluroShield after gamma sterilization.

\begin{tabular}{lccc}
\hline Treatment & $\begin{array}{c}\text { Gamma } \\
\text { sterilization* } \\
(\mathrm{n}=6)\end{array}$ & $\begin{array}{c}\text { Non-gamma } \\
\text { sterilization } \\
(\mathrm{n}=6)\end{array}$ & $\mathrm{p}$ value \\
\hline $\begin{array}{l}\text { Clearfil Protect } \\
\text { Bond }\end{array}$ & $21.89(0.99)^{\mathrm{a}}$ & $22.25(1.38)^{\mathrm{a}}$ & 0.616 \\
& & & \\
FluroShield & Zero & Zero & \\
\hline
\end{tabular}

* Values are expressed as mean (standard deviation) in mm. Different letters in rows indicate statistically significant difference (ANOVA and Tukey's test; $\mathrm{p}<0.05$ ). 


\section{DISCUSSION}

Gamma sterilization affected the fluoride release of FS, while fluoride release of Clearfil Protect Bond was not affected. As fluoride incorporation method differs between the materials, fluoride release also occurs in different ways. Several factors can contribute to fluoride release: amount of fluoride, type and size of fluoridated particle, type of resin, silane treatment and porosity, hydrophilicity and the acid character of the polymer matrix (12). In FS, fluoride is added to unpolymerized resin in the form of a soluble salt ( $2 \%$ sodium fluoride) and its release results from the dissolution of this salt (13). In $\mathrm{CPB}$, fluoride is present as $\mathrm{NaF}$ crystal-like structures (14), which are referred to by the manufacturer as being surface treated sodium fluoride $(<1 \%)$.

The effects of gamma irradiation on the properties of restorative resins in vitro were evaluated by von Fraunhofer et al. (15). The authors used a dose (80 Gy) to simulate radiation therapy for cancer treatment, which is lower than the $14.5 \mathrm{KGy}$ dose used in this study. However it is known that the physical and mechanical properties of irradiated material are dose-dependent (16). Thus, the higher the dose used, the higher the alteration in properties. von Fraunhofer et al. (15) found that gamma irradiation induced hardening of the outer layer (air-inhibited) of light-polymerized resins and reduced the water sorption and solubility. These results were explained by the increase in the conversion degree of resins caused by gamma irradiation because this procedure has a greater intensity and higher penetrating power than the visible light used to activate the composite polymerization. Moreover, gamma irradiation increases the surface hardness and decreases the water sorption and solubility of resin materials. The present study showed that it also influenced the fluoride release in resin materials with sodium fluoride in the matrix. Interestingly, in a pilot study, the specimens that received gamma irradiation were partially polymerized inside the Eppendorf tubes, visibly showing the increase in the conversion degree.

Since gamma irradiation has the potential to increase the conversion degree of composite resin materials and decrease the water sorption and solubility (15), it can also reduce the fluid ingress into the structure of resin materials, decrease fluoride/water contact and fluoride movement in the matrix, resulting in lower fluoride release (17). This was observed in this study. Gamma sterilization decreased the fluoride release in FS by almost
$50 \%$. However, when fluoride was present as fillers or crystals, no difference was found between sterilized and nonsterilized groups. This could be due to the presence of $\mathrm{NaF}$ crystals-like structures on the surfaces that might have released fluoride even after gamma irradiation.

The fluoride release values of sealant and adhesive system obtained in the present study were higher than those of other studies $(1,18)$ because resin material disks release more fluoride than the material bonded to enamel or dentin. In restorations, fluoride discharge is low, restricted only the enamel/sealant and dentin/ adhesive interactions $(1,18)$. The specific electrode is not able to detect low concentrations of fluoride ions released by materials bonded to enamel or dentin (18).

MDPB (present in CPB) is a compound of the antibacterial agent quaternary ammonium and a methacryloyl group. It is covalently bound to the polymer matrix by its copolymerization with other monomers when the material is polymerized (19), and MDPB becomes immobilized in the polymer matrix. The antibacterial activity after polymerization occurs by contact, without MDPB leaching out from the matrix (11).

Generally, the agar-disc diffusion method is used to evaluate the antibacterial activity of materials from which an antibacterial component leaches out. In this study, the increase in the conversion degree caused by gamma irradiation did not affect the antibacterial activity of MDPB because it remained in contact with $S$. mutans colonized on the agar. Imazato et al. (11) showed that polymerized MDPB primer produced no inhibition zones, but it had inhibitory effects against bacteria in contact with the material surface. All FS specimens were polymerized before the test and, as there was no water to release, the fluoride did not diffuse in the agar and the zone of microbial growth inhibition against $S$. mutans was null. However, it would not be possible to test the antibacterial effect of FS after gamma irradiation with fluid specimens because they could be polymerized during the irradiation process, invalidating the analysis. Loyola-Rodriguez and Garcia-Godoy (20) did not find antibacterial effect of FluroShield against $S$. mutans either. Furthermore, clinically, fluoride is known to inhibit the biosynthetic metabolism of bacteria, but these antimicrobial effects in caries prevention are often regarded as being of little or no importance when compared with the direct interaction of fluoride with the hard tissue during caries development and progression (12).

Some studies have tested the cariostatic effect 
of dental materials with biological models, in which specimens were previously sterilized before immersion in culture broth with microorganisms, but the effect of sterilization on cariostatic properties has not been evaluated (5). The real importance of this study is to determine whether gamma sterilization can be used in specimens before immersing them in the biological model in vitro. This study showed that the biological model is not applicable to FS when gamma sterilization is used, because it decreases the fluoride release. Other models should be used to simulate artificial caries and evaluate the cariostatic effect of FS, such as $\mathrm{pH}$ cycling and acid gels, which do not require previous sterilization. In contrast, gamma sterilization did not affect the fluoride release and antibacterial activity of CPB, making it a safe sterilization method for verifying the cariostatic effect of this material when using a biological model.

\section{RESUMO}

Este estudo avaliou o efeito da esterilização com raios-gama na liberação de flúor e atividade antibacteriana de materiais resinosos, Fluroshield (FS) e Clearfil Protect Bond (CPB). Quatro grupos foram formados: G1-FS e gama; G2-FS sem gama; G3-CPB e gama; G4-CPB sem gama. Doze discos de cada material foram preparados para análise de liberação de flúor, os quais foram cobertos com esmalte de unha, exceto em um lado com 50,4 $\mathrm{mm}^{2}$ de área. G1 e G3 foram esterilizados com dose de 14,5 KGy por $24 \mathrm{~h} / 27^{\circ} \mathrm{C}$, enquanto $\mathrm{G} 2 \mathrm{e} \mathrm{G} 4$ (controles) não foram esterilizados e foram mantidos sob as mesmas condições de tempo e temperatura. As leituras de liberação de flúor foram feitas em duplicata $(n=6)$ por um eletrodo específico. A atividade antibacteriana foi avaliada pelo teste de difusão em agar. Os halos de inibição foram medidos após $48 \mathrm{~h}$. Os dados foram analisados pelos testes ANOVA e Tukey $(\alpha=5 \%)$. A esterilização gama diminuiu a liberação de flúor de FS em cerca de 50\%, enquanto CPB não foi afetado. Não houve diferença estatisticamente significante entre os grupos esterilizados e controle no efeito antibacteriano do CPB. FS não apresentou atividade antibacteriana. A esterilização gama diminuiu a liberação de flúor de FS, mas não afetou a atividade antibacteriana dos materiais estudados.

\section{ACKNOWLEDGEMENTS}

The authors are grateful to Paulo Neto and Benedita Rodrigues from CENA/USP for the gamma irradiation procedures and Kuraray Co. for supplying CPB. This study was supported by grants (\#05/57268-9 and \#05/60595-1) from the São Paulo State Research Foundation (FAPESP).

\section{REFERENCES}

1. Kantovitz KR, Pascon FM, Correr GM, Borges AF, Uchoa MN, Puppin-Rontani RM. Inhibition of mineral loss at the enamel/sealant interface of fissures sealed with fluoride- and non-fluoride contain- ing dental materials in vitro. Acta Odontol Scand 2006;64:376-383.

2. Lobo MM, Goncalves RB, Pimenta LA, Bedran-Russo AK, Pereira PN. In vitro evaluation of caries inhibition promoted by self-etching adhesive systems containing antibacterial agents. J Biomed Mater Res B Appl Biomater 2005;75:122-127.

3. Salar DV, Garcia-Godoy F, Flaitz CM, Hicks MJ. Potential inhibition of demineralization in vitro by fluoride-releasing sealants. J Am Dent Assoc 2007;138:502-506.

4. Rodrigues JA, Marchi GM, Serra MC, Hara AT. Visual evaluation of in vitro cariostatic effect of restorative materials associated with dentifrices. Braz Dent J 2005;16:112-118.

5. Carvalho FG, Fucio SB, Sinhoreti MA, Correr-Sobrinho L, Puppin-Rontani RM. Confocal laser scanning microscopic analysis of the depth of dentin caries-like lesions in primary and permanent teeth. Braz Dent J 2008;19:139-144.

6. Kawai K, Takaoka T. Inhibition of bacterial and glucan adherence to various light-cured fluoride-releasing restorative materials. J Dent 2001;29:119-122.

7. van Loveren C. Antimicrobial activity of fluoride and its in vivo importance: identification of research questions. Caries Res 2001;35:65-708.

8. Thomas RZ, Ruben JL, Ten Bosch JJ, Huysmans MC. Effect of ethylene oxide sterilization on enamel and dentin demineralization in vitro. J Dent 2007;35:547-551.

9. Amaecha BT, Higham SM, Edgar WM. Effect of sterilization methods on the structural integrity of artificial enamel caries for intra-oral cariogenicity tests. J Dent 1999;27:313-316.

10. Carvalho FG, Gonçalves LS, Carlo HL, Soares CJ, Correr-Sobrinho, Puppin-Rontani RM. Influence of sterilization method on the bond strength of caries-affected dentin. Braz Oral Res 2009; 23:11-16.

11. Imazato S, Ehara A, Torii M, Ebisu S. Antibacterial activity of dentine primer containing MDPB after curing. J Dent 1998;26:267-271.

12. Wiegand A, Buchalla W, Attin T. Review on fluoride-releasing restorative materials-fluoride release and uptake characteristics, antibacterial activity and influence on caries formation. Dent Mater 2007;23:343-362.

13. Morphis TL, Toumba KJ, Lygidakis NA. Fluoride pit and fissure sealants: a review. Int J Paediatr Dent 2000;10:90-98.

14. Sidhu SK, Omata Y, Tanaka T, Koshiro K, Spreafico D, Semeraro $\mathrm{S}$, et al.. Bonding characteristics of newly developed all-in-one adhesives. J Biomed Mater Res B Appl Biomater 2007;80:297-303.

15. von Fraunhofer JA, Curtis P Jr, Sharma S, Farman AG. The effects of gamma radiation on the properties of composite restorative resins. J Dent 1989;17:177-183.

16. Cheung DT, Perelman N, Tong D, Nimmi ME. The effect of gamma-irradiation on collagen molecules, isolated alpha-chains and crosslinked native forces. J Biomed Mater Res 1990;24:581-589.

17. Toba S, Pereira PNR, Nikaido T, Tagami J. Effect to topical application of fluoride gel on artificial secondary caries inhibition. Int Chin J Dent 2003;3:53-61.

18. Peris AR, Mitsui FH, Lobo MM, Bedran-Russo AK, Marchi GM. Adhesive systems and secondary caries formation: Assessment of dentin bond strength, caries lesions depth and fluoride release. Dent Mater 2007;23:308-316.

19. Imazato S, McCabe JF. Influence of incorporation of antibacterial monomer on curing behavior of a dental resin composite J Dent Res 1994;73:1641-1645

20. Loyola-Rodriguez JP, Garcia-Godoy F. Antibacterial activity of fluoride release sealants on mutans streptococci. J Clin Pediatr Dent 1996;20:109-111. 